\title{
Present Position of Agriculture in India
}

\author{
B P Sharma
}

\begin{abstract}
Agriculture is facing problem due to monsoon and government has taken certain initiatives to encourage and protect agriculture.
\end{abstract}

Keywords: agriculture, economy, goverment, budget, disaster management

\section{Introduction}

India was dependent on import and food aid to meet domestic food requirement in sixties. Subsequently under the green revolution we attained self sufficiency by adopting superior yielding, disease resistant wheat varieties with better farming knowledge

India's agricultural economy has undergone structural changes during the period between 1970 and 2014; the GDP share of agriculture has fallen from 43 to $14 \%$. This isn't because of reduced importance of agriculture, or a consequence of agricultural policy. This is largely because of the rapid economic growth in services, industrial output, and non-agricultural sectors in India.

Two states, Sikkim and Kerala have planned to shift to a fully organic farming by 2015 and 2016 respectively.

Despite the focus on industrialisation, agriculture remains a dominant sector of the Indian economy both in terms of contribution to gross domestic product (GDP) as well as a source of employment to millions across the country.

Agriculture plays a vital role in the Indian economy. Over 70 per cent of the rural households depend on agriculture as their principal means of livelihood.

The total Share of Agriculture \& Allied Sectors (Including agriculture, livestock, forestry and fishery sub sectors) in terms of percentage of GDP is 13.9 percent during 2013-14 at 2004-05 prices. [As per the estimates released by Central Statistics Office].

Agricultural exports constitute a fifth of the total exports of the country. In view of the predominant position of the Agricultural Sector, collection and maintenance of Agricultural Statistics assume great importance.

The country is also the largest producer, consumer and exporter of spices and spice products in the world and overall it is ranked second in farm and agriculture outputs. From canned, dairy, processed, frozen food to fisheries, meat, poultry, and food grains, the Indian agro industry has plenty of areas to choose for business.

Spice exports from India are expected to reach US\$ 3 billion by 2016-17, on the back of creative marketing strategies, innovative packaging, strength in quality and a strong distribution network. The Indian spices market is pegged at Rs 40,000 crore (US\$ 6.42 billion) annually, of which the branded segment accounts for 15 per cent.
With an annual output of $130 \mathrm{MT}$, India is the largest producer of the milk in the world. It also has the largest milk-producing animal population of over 118 million. However, milk yields per animal are among the lowest in the world. India is the biggest producer of pulses in the world at 19 MT and their biggest importer 3.5 MT. India is the second largest producer of sugar in the world and the government has aimed to increase the exports from 1.3 MT in 2013 to an average of 2 MT in 2014 and 2015.

In 2013-14 India achieved a record food grain production of 265 MT, beating the previous year's (2012-13) 257 MT, according to data provided by Department of Economics and Statistics (DES). Also, agricultural profitability has increased over the last decade with record increases in MSPs (minimum support prices) for agricultural produce for all covered crops. India's food-grain production will report a decline of $3 \%$ 2014-15 putting the total food-grain production at 257.07 million tons in current crop year (JulyJune period) as compared to the highest ever food-grain production of 265.57 million tons in 2013-14. "This decline has occurred on account of lower production of rice, coarse cereals and pulses due to erratic rainfall conditions during monsoon season in 2014", said the ministry in its estimate report.

\section{Irrigation}

Indian irrigation infrastructure includes a network of major and minor canals from Indian rivers; groundwater well based systems, tanks, and other rainwater harvesting projects for agricultural activities. Of these groundwater system is the largest. Of the 160 million hectares of cultivated land in India, about 39 million hectare can be irrigated by groundwater wells, and an additional 22 million hectares by irrigation canals. Only about $35 \%$ of total agricultural land in India was reliably irrigated. About 2/3rd cultivated land in India is dependent on monsoons.

India's arable land area of 159.7 million hectares (394.6 million acres) is the second largest in the world, after the United States. Its gross irrigated crop area of 82.6 million hectares (215.6 million acres) is the largest in the world. India is among the top three global producers of many crops, including wheat, rice, pulses, cotton, peanuts, fruits and vegetables. Worldwide, as of 2011, India had the largest herds of buffalo and cattle, is the largest producer of milk and has one of the largest and fastest growing poultry industries.

In addition to growth in total output, agriculture in India has shown an increase in average agricultural output per hectare 


\section{International Journal of Science and Research (IJSR) \\ ISSN (Online): 2319-7064 \\ Index Copernicus Value (2013): 6.14 | Impact Factor (2015): 6.39}

in last 60 years. Improving road and power generation infrastructure, knowledge gains and reforms has helped India to increase farm productivity between $40 \%$ to $500 \%$ over 40 years. India's recent accomplishments in crop yields while being impressive, are still just $30 \%$ to $60 \%$ of the best crop yields achievable in the farms of developed as well as other developing countries.

\section{Problems}

India lacks cold storage, food packaging as well as safe and efficient rural transport system. This causes one of the world's highest food spoilage rates, particularly during Indian monsoons and other adverse weather conditions. Food travels to the Indian consumer through a slow and inefficient chain of traders.

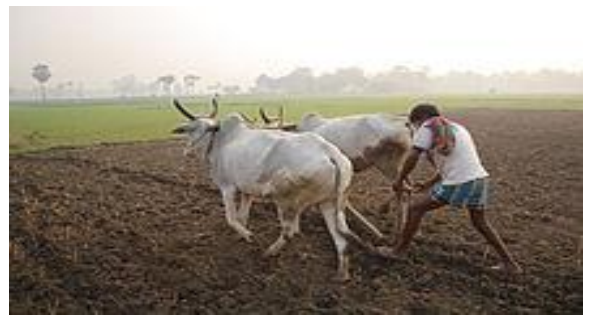

Indian agriculture includes a mix of traditional to modern farming techniques. In some parts of India, traditional use of cattle to plough farms remains in use which has some of the lowest per capita productivities and farmer incomes.Since 2002, India has become the world's largest manufacturer of tractors with 29\% of world's output in 2013; it is also the world's largest tractor market.

"Slow agricultural growth of $1.5-2 \%$ is a concern for policymakers as some two-thirds of Indiaes people depend on rural employment for a living. Current agricultural practices are neither economically nor environmentally sustainable and India's yields for many agricultural commodities are low. Poorly maintained irrigation systems and almost universal lack of good extension services are among the factors responsible. Farmers' access to markets is hampered by poor roads, rudimentary market infrastructure, and excessive regulation."

\section{- World Bank: "India Country Overview 2008"}

Encouraging policies that promote competition in agricultural marketing will ensure that farmers receive better prices."

\section{- World Bank: "India Country Overview 2011"}

\section{Infrastructure}

India has very poor rural roads affecting timely supply of inputs and timely transfer of outputs from Indian farms. Irrigation systems are inadequate leading to crop failures in some parts of the country because of lack of water. In other areas regional floods, poor seed quality and inefficient farming practices, lack of cold storage and harvest spoilage cause over $30 \%$ of farmer's produce going to waste, lack of organised retail and competing buyers thereby limiting Indian farmer's ability to sell the surplus and commercial crops.
The Indian farmer receives just 10 to $23 \%$ of the price the Indian consumer pays for exactly the same produce, the difference going to losses, inefficiencies and middlemen.

\section{Productivity}

Although India has attained self-sufficiency in food staples, the productivity of Indian farms is below that of Brazil, the United States, France and other nations. Indian wheat farms, for example, produce about a third of the wheat per hectare per year compared to farms in France. Rice productivity in India was less than half that of China.

Our food distribution system is highly inefficient. Movement of agricultural produce within India is heavily regulated, with inter-state and even inter-district restrictions on marketing and movement of agricultural goods.

One study suggests Indian agricultural policy should best focus on improving rural infrastructure primarily in the form of irrigation and flood control infrastructure, knowledge transfer of better yielding and more disease resistant seeds. Additionally, cold storage, hygienic food packaging and efficient modern retail to reduce waste can improve output and rural incomes.

The low productivity in India is a result of the following factors:

- The average size of land holdings is very small (less than 2 hectares) and is subject to fragmentation due to land ceiling acts, and in some cases, family disputes. Such small holdings are often over-manned, resulting in disguised unemployment and low productivity of labour.

- Adoption of modern agricultural practices and use of technology is inadequate, hampered by ignorance of such practices, high costs and impracticality in the case of small land holdings.

- According to the World Bank, Indian Branch: Priorities for Agriculture and Rural Development", India's large agricultural subsidies are hampering productivityenhancing investment. The allocation of water is inefficient, unsustainable and inequitable. The irrigation infrastructure is deteriorating.

- The overuse of water is currently being covered by over pumping aquifers, but as these are falling by foot of groundwater each year, this is a limited resource.

- Inconsistent government policy. Agricultural subsidies and taxes often changed without notice for short term political ends.

- Irrigation facilities are inadequate, as revealed by the fact that only $35 \%$ of the land was irrigated which result in farmers still being dependent on rainfall, specifically the Monsoon season

- A third of all food that is produced rots due to inefficient supply chains

\section{Farmer Suicides}

The National Crime Records Bureau of India reported 13,754 farmer suicides. Farmer suicides account for $11.2 \%$ of all suicides in India. Activists and scholars have offered a number of conflicting reasons for farmer suicides, such as monsoon failure, high debt burdens, genetically modified crops, public mental health, personal issues and family problems.

\section{Volume 5 Issue 4, April 2016}




\section{International Journal of Science and Research (IJSR) \\ ISSN (Online): 2319-7064 \\ Index Copernicus Value (2013): 6.14 | Impact Factor (2015): 6.39}

Diversion of agricultural land for non agricultural purpose

Indian National Policy for Farmers of 2007 stated that "prime farmland must be conserved for agriculture except under exceptional circumstances, provided that the agencies that are provided with agricultural land for non-agricultural projects should compensate for treatment and full development of equivalent degraded or wastelands elsewhere". The policy suggested that, as far as possible, land with low farming yields or that was not farmable should be earmarked for non-agricultural purposes such as construction, industrial parks and other commercial development.

Amartya Sen offered viewpoint, that prohibiting the use of agricultural land for commercial and industrial development is ultimately self-defeating if industrial production could generate many times more than the value of the product produced by agriculture.

The required level of investment for the development of marketing, storage and cold storage infrastructure is estimated to be huge. The government has been able to implement various schemes like Construction of Rural Godowns, Market Research and Information Network, and Development / Strengthening of Agricultural Marketing Infrastructure, Grading and Standardisation.

\section{Investments}

he Indian agricultural services and the agricultural machinery sectors have cumulatively attracted foreign direct investment (FDI) equity inflows to the tune of US\$2,153.61 million in the period April 2000-December 2014, according to the Department of Industrial Policy and Promotion (DIPP).

Some of the major investments and developments in agriculture in the recent past are as follows:

- IVRCL Ltd's irrigation and water divisions have won orders worth Rs 1,255.67 crore (US\$ 201.58 million). The company is based out of Hyderabad.

- The Oman India Joint Investment Fund (OIJIF), a joint venture (JV) between State Bank of India (SBI) and State General Reserve Fund (SGRF), has invested Rs 95 crore (US\$ 15.25 million) in GSP Crop Science, a Gujaratbased agrochemicals company.

- Israel based world's seventh largest agrochemicals firm ADAMA Agrochemicals plans to invest at least US\$ 50 million in India over the next three years.

- Tafe Motors and Tractors Ltd (TAFE) has invested around US\$ 140 million by way of equity in the US-based AGCO Corporation, a worldwide manufacturer and distributor of agricultural equipment.

- Canada is keen to partner with India in the agriculture and processing sectors, particularly in pulses and canola.

\section{Current Problems}

Due to untimely rains and shift in monsoon season farmers are finding it difficult to grow crops, even if crops are grown there was damage due to hail storms during harvest. After harvesting procurement is delayed. Insurance claim for damage crops is not assessed timely and properly. Last crops have failed and current season monsoon is also likely to be low.

$55-60 \%$ population is dependent on agriculture, share in GDP is about $14 \%$ and last year growth is only $0.2 \%$. Average growth for last 3 years is $1.7 \%$. Higher growth is possible as 5 states in India have shown average growth of $7 \%$ and above in decade. e.g. Gujarat-9.8\%, Rajasthan9.6\%, Chhattisgarh-8.9\%,madhyapradesh-7.4\% and Jharkhand- $6.9 \%$.

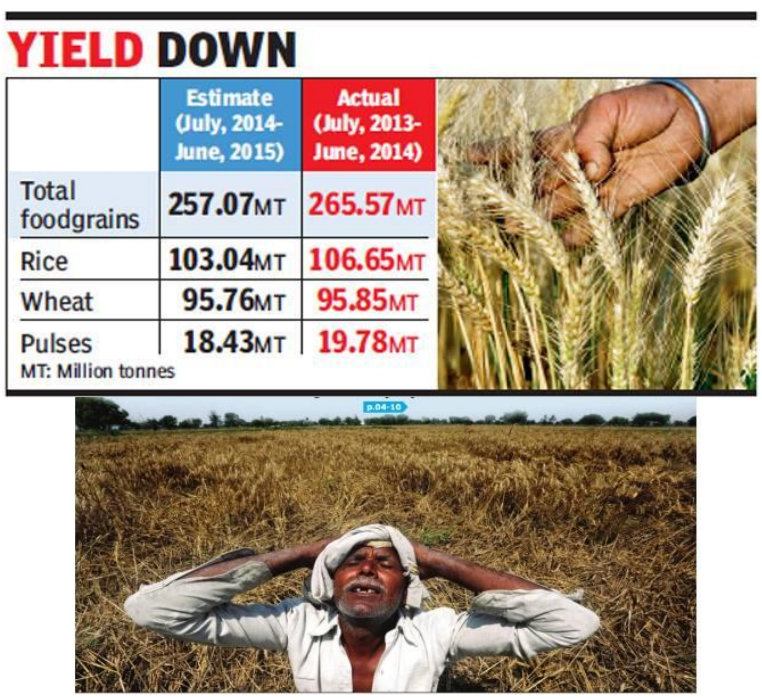

Food grain production- 2013-14 265.57 MT, 2014-15 257.07 MT, 2015-16 253.16 MT.

\section{Government Initiatives}

Recognizing the importance of Agriculture Sector, the Government during the budget 2015-16 and 2016-17 took a number of steps for sustainable development of Agriculture.

- Enhanced institutional credit to farmers;

- Promotion of scientific warehousing infrastructure including cold storages and cold chains in the country for increasing shelf life of agricultural produce;

- Approved access to irrigation through Pradhan Mantri Krishi Sichayee Yojana;

- Provision of Price Stabilisation Fund to mitigate price volatility in agricultural

- Setting up of Agri-tech Infrastructure fund "Bhoomi Heen Kisan" through NABARD;

- Development of indigenous cattle breeds and promoting inland fisheries.

- sustainable management of ground water resources with cost of Rs 6,000 crore .

- At least 5 lakh farm ponds ,dug wells and 10 lakh compost pits for organic manure.

- The Soil Health Card Scheme for judicious use of fertilizers. A policy for conversion of city waste into compost the Swachh Bharat Abhiyan.

- To increase crop yields in rain fed areas for nearly 55\% of the country's arable land, organic farming is being promoted. The Government has launched two schemes. First, the „Parmparagat Krishi Vikas Yojana ${ }^{e e}$ which will bring 5 lakh acres under organic farming. Second, an organic farming scheme called "Organic Value Chain 
Development in North East Region".with a provision of Rs 412 crore .

- Rs 500 crores under National Food Security Mission. A national level competition will be held among 674 Krishi Vigyan Kendras with a prize money of Rs 50 lakh The Unified Agriculture Marketing Scheme which envisages a common e-market platform that will be deployed in selected 585 regulated wholesale markets. Amendments to the APMC Acts of States are a pre-requisite to join this eplatform.

- The government allocated Rs 19,000 crore for Pradhan Mantri Gram Sadak Yojana in 2016-17.

- Special focus has been given to ensure adequate and timely flow of credit to the farmers. Against the target of Rs 8.5 lakh crore in 2015-16, the target for agricultural credit in 2016-17 will be an all-time high of Rs 9 lakh crore. To reduce the burden of loan repayment on farmers, a provision of Rs 15,000 crore has been made in the BE 2016-17 towards interest subvention.

- Government has approved the Crop Insurance Scheme, namely, Prime Minister Fasal Bima Yojana. For effective implementation of this Scheme, the govt has provided a sum of Rs 5,500 crore in the Budget 2016-17.

- 28.5 lakh hectares will be brought under irrigation under the Pradhan Mantri Krishi Sinchai Yojana. -

\section{Various aspects of National Disaster Response Fund norms:}

- The enhanced input subsidy norms in various categories are as follows:

- In case of agriculture crops, horticulture crops and annual plantation crops, the input subsidy has been hiked from Rs 4500 per hectare to Rs 6800 per hectare in rained areas and restricted to sown areas. In the assured irrigated areas, it has been hiked from Rs 9000 per hectare to Rs 13500 per hectare.

- In case of perennial crops, subsidy has been hiked from Rs 12000 to Rs 18000 .

- For sericulture, subsidy hiked from Rs 3200 - Rs 4000 to Rs 4800 - Rs 6000 .

- The assistance for land and other losses due to silting of agricultural land has been increased from Rs 8100 per hectare to Rs 12200 per hectare. also to removal of debris of agricultural land in hilly areas and restoration or repair of fish farms.

- In case of loss of substantial portion of land due to land slide, avalanche, change of course of rivers, assistance hiked from Rs 25000 per hectare to Rs 37500 .

- Providing respite to the small and marginal farmers engaged in animal husbandry,

- For the replacement of milch animals, from Rs 16400 to Rs 30000. In case of replacement of sheep/goat, raised from Rs 1650 to Rs 3000. In case of replacement of draught animals, from Rs 15000 to Rs 25000 For the replacement of calf/donkey/pony/mule, the raised from Rs 10000 to Rs 16000.

\section{References}

[1] The Economic Survey, Agricultural and Processed Food Products Export Development Authority (APEDA), The Union Budget 2014-15, Press Releases, Media Reports

[2] Press Information Bureau Government of India Ministry of Agriculture 10-April-2015

[3] "India Country Overview 2008". World Bank. 2008.

[4] "India Country Overview 2011". World Bank. 2011.

[5] "India: Priorities for Agriculture and Rural Development". World Bank.

[6] Schuman, R. (2013), Shadow space: suicides and the predicament of rural India, Journal of Peasant Studies, 40(3), 597-601 